\title{
Determining hydraulic connectivity of the coastal aquifer system of La Plata river estuary (Argentina) to the ocean by analysis of aquifer response to low-frequency tidal components
}

\author{
Mar Alcaraz $^{1,2}$ (D) Jesús Carrera ${ }^{3} \cdot$ Julián Cuello $^{2} \cdot$ Luis Guarracino $^{2,4} \cdot$ Luis Vives $^{1}$ \\ Received: 27 July 2020 / Accepted: 3 March 2021 / Published online: 1 April 2021 \\ (C) Springer-Verlag GmbH Germany, part of Springer Nature 2021
}

\begin{abstract}
Seawater intrusion occurs in almost all coastal aquifers that are subject to human pressure. Its effects could be reduced by avoiding pumping in those wells better hydraulically connected to the sea. This paper presents a methodology to assess hydraulic connection to the sea of a well from its response to sea-level fluctuations. Head fluctuations in a well result from the superposition of hydraulic and hydro-mechanical responses. The hydraulic response requires a good hydraulic connection to the sea, whereas a hydro-mechanical response suggests a poor connection. Sea level fluctuates with a broad range of harmonics, which allows identification of the hydraulic and hydro-mechanical responses based on the harmonic frequency. It is shown that the response to low-frequency harmonics is essentially hydraulic and the response to high-frequency harmonics is mainly hydro-mechanical. The proposed methodology facilitates the discrimination of both responses with the aim to study qualitatively the hydraulic connection to the sea. This methodology is applied to the aquifer system of La Plata river estuary in western Argentina. Surprisingly, the hydraulic response of the deepest aquifer (Paraná) is less damped than the response of the overlaying aquifer (Puelches). This finding suggests that the Paraná aquifer is better connected to the sea than the Puelches.
\end{abstract}

Keywords Groundwater management · Coastal aquifers · Tidal loading · Frequency components · Argentina

\section{Introduction}

Seawater intrusion is a common problem in coastal aquifers, often because of human activity. As a result, the groundwater resource is impacted qualitatively and quantitatively (Bear et al. 1999; He et al. 2020). Groundwater management policies should be devised in order to reduce, avoid and even reverse the negative effects of seawater intrusion (Renau-

Mar Alcaraz

malcaraz@ihlla.org.ar

1 Instituto de Hidrología de Llanuras Dr. Eduardo Usunoff, República de Italia, 78, B7300 Azul, Provincia de Buenos Aires, Argentina

2 Consejo Nacional de Investigaciones Científicas (CONICET), C1066AAJ Ciudad Autónoma de Buenos Aires, Av. Rivadavia, 1917, Buenos Aires, Argentina

3 GHS UPC-CSIC Institute of Environmental Assessment and Water Research (IDÆA-CSIC), Jordi Girona 18, 08034 Barcelona, Spain

4 Facultad de Cs. Astronómicas y Geofísicas, Universidad Nacional de La Plata, Paseo del Bosque s/n, 1900 La Plata, Argentina
Pruñonosa et al. 2016). While sustainable resource management policies are being designed and implemented, transition solutions are needed to delay seawater intrusion. One of these preventative measures would be to avoid pumping in those wells best connected to the ocean, which would tend to attract seawater when pumped, and focus the water extraction in poorly connected wells, which would tend to draw inland water. The problem is similar to pumping near a polluted river (Ahring et al. 2020). Thus, characterization of the hydraulic connection of existing wells to the ocean, or in general, prescribed head lines such as rivers, becomes a critical issue (Alvarez et al. 2019; Park et al. 2012).

There is no standard way to evaluate the hydraulic connection of a well to the sea because connectivity depends on the processes active at the site (Knudby and Carrera 2005; Renard and Allard 2013) and connectivity is generally viewed as having a qualitative character (Trinchero et al. 2008). In general, connectivity implies the existence of preferential flow paths and it is related to the heterogeneity of the geological materials, which may favor the existence of permeable pathways (Willmann et al. 2008; Slooten et al. 2010; Bianchi et al. 2011; Giudici et al. 2012; Tyukhova and Willmann 2016). 
Permeable pathways tend to increase effective transmissivity (flow connectivity) and reduce first arrival time (transport connectivity) or the time the well takes to respond to fluctuations in the sea or river (hydraulic diffusion connectivity). Retarding the transport of pollutants from the sea or river requires a reduced transport connectivity, but this is hard to assess experimentally. Knudby and Carrera (2006) show that hydraulic diffusivity could be a good indicator of transport connectivity.

A feasible option to measure the hydraulic diffusivity in coastal aquifers could be through the aquifer response to sea tides. Ferris (1951) derived an analytical solution to show that tidal fluctuations are damped and delayed in the aquifer, which should facilitate deriving the hydraulic diffusivity of the aquifer. Since then, numerous analytical solutions have been developed to reproduce the behavior of aquifers subject to ocean tidal influences for different conditions ( $\mathrm{Li}$ and Jiao 2003a, b; Asadi-Aghbolaghi et al. 2014; Chuang and Der Yeh 2011; Cuello et al. 2017; Hsieh et al. 2015; Jiao and Tang 1999; Knight and Rassam 2007; Monachesi and Guarracino 2011; Song et al. 2007; Teloglou and Bansal 2012; Teo et al. 2003; Wang et al. 2014; and references therein). These analytical solutions can be applied in order to obtain the hydraulic diffusivity $\left(D_{\mathrm{h}}\right)$ from the tidal response method as proposed by Ferris (1951).

According to this method, $D_{\mathrm{h}}$ can be obtained from observations of amplitude damping or phase shift. Commonly, $D_{\mathrm{h}}$ values obtained from damping are different from those obtained from the phase shift (Jha et al. 2008; Fadili et al. 2016; Shirahata et al. 2018). These differences may reflect that aquifers are heterogeneous (Trefry and Bekele 2004), or that the observed response is a superposition of several effects (Vallejos et al. 2014), such as atmospheric pressure variations, marine hydrodynamics, precipitation events, pumping regime or presence of confining layers. Among them, tidal loading could be one of the most systematic effects in aquifers that extend under the sea.

Tidal loading, which affects aquifers extending under the sea, could disturb groundwater observations in inland wells because it induces a mechanical perturbation in the submerged aquifer. The sea level variations imply a loading in the aquifer that is transferred to the offshore portion of the aquifer as pressure waves. The elastic behavior of the aquifer is responsible for mechanical perturbations under surface load variations because the aquifer behaves like a sponge (Narasimhan et al. 1984). When the ocean level is rising, the load over the aquifer is increased. Depending on elastic properties of the aquifer materials, this load could be completely absorbed by the solid structure of the aquifer if it was fully uncompressible or rigid. However, natural materials are never so stiff; in fact, in unconsolidated sediments, most of the load is transferred to groundwater (Meinzer 1928; Terzaghi 1925, 1954). This increase in water pressure causes groundwater to flow inland and head to drop. As head drops, the solid structure takes up the load and deforms by reducing the porosity. Effectively, water is squeezed inland from the submarine portion of the aquifer. The elastic response of aquifers is usually evaluated with specific parameters such as barometric efficiency, tidal efficiency or loading efficiency (Jacob 1940; Bredehoeft 1967; Rasmussen and Crawford 1997), which quantify the fraction of the load taken by water and by the solid structure.

The mechanical perturbation induced under the sea by tidal loading will diffuse hydraulically into the aquifer inland, and a hydro-mechanical response will be observed in inland wells. Several analytical solutions have been developed to reproduce the hydro-mechanical response under different geometrical configurations of coastal aquifer systems and boundary conditions (van der Kamp 1972; Li and Jiao 2001; Li et al. 2008; Geng et al. 2009; Wang et al. 2012; Guarracino et al. 2012, and references therein).

It is important to realize that a hydro-mechanical or elastic response under tidal loading does not imply hydraulic connectivity. A perfectly confined aquifer with a null hydraulic connection to the sea may still display a head response to sea level fluctuations, which would be purely mechanical. Conversely, an unconfined aquifer extending under the sea will display a negligible mechanical effect because squeezed water will tend to flow towards the sea rather than inland. This leads to a paradox-one would expect that a fast aquifer response to tides implies a good connection to the sea; however, in reality, if this response is hydro-mechanical, a fast response might indicate the opposite.

The question that arises is whether an observed response to sea level fluctuations is hydraulic, thus indicating a good hydraulic connection to the sea offshore, or hydro-mechanical, thus suggesting a poor hydraulic connection. The objective of this work is to discriminate the hydraulic from the hydromechanical response in order to analyze the hydraulic connection of the aquifer to the sea. This discrimination is based on the different behaviors of hydraulic and hydro-mechanical responses to low and high-frequency components of sea tides. The novelty of this work lies in the isolation of low-frequency components of aquifer heads, as this response contains information about the hydraulic connection of the aquifer to the sea offshore.

\section{Methodology}

\section{Basic conjecture}

The proposal is to take advantage of the fact that tidal signal encompasses numerous harmonics of different frequencies, because of the different components of tides and other causes of sea level fluctuations (atmospheric pressure, winds...) (Pugh 1987). Every harmonic of this spectrum produces both 
hydraulic and hydro-mechanical responses in the aquifer under the usual boundary conditions (aquifer open to the sea offshore and a leaky aquitard over the aquifer). But the amplitude damping and phase shift of these two responses is different and frequency dependent.

The goal is to test the conjecture that hydraulic connection can be determined from the response to low-frequency sea level fluctuations, whereas mechanical effects are more important for high-frequency fluctuations. In the following sections, this conjecture is first developed in mathematical terms and then analyzed to determine its implications.

\section{Principles of hydraulic and hydro-mechanical re- sponses to tides}

\section{Governing equations}

Coupled hydro-mechanical behavior is defined by the conventional flow equation with an additional term to represent the mechanical effect as a distributed source term (Rice and Cleary 1976; Van Der Kamp and Gale 1983, although the concept was quite clearly expressed by Meinzer in 1928, see p. 277):

$S_{\mathrm{S}} \frac{\partial h}{\partial t}=\nabla(K \nabla h)+S_{\mathrm{S}} L_{\mathrm{e}} \frac{d h_{\mathrm{s}}}{d t}$

where $h$ represents head fluctuations [L]; $S_{\mathrm{S}}$ and $K$ are the specific storage $\left[\mathrm{L}^{-1}\right]$ and the hydraulic conductivity $\left[\mathrm{LT}^{-1}\right]$ of the aquifer, respectively; $h_{\mathrm{s}}$ is the sea level fluctuation [L] and $d h_{\mathrm{s}} / d t$ is its time derivative; and $L_{\mathrm{e}}$ is the tidal loading efficiency [-], which quantifies the fraction of the load taken by water and by the solid structure. The last term only applies to the submerged portion of the domain. To honor Meinzer, $S_{\mathrm{S}} L_{\mathrm{e}} d h_{\mathrm{s}} / d t$ is called the "squeezing term", as it represents "water that is squeezed out of the sand" (Meinzer 1928).

Equation (1) is solved subject to appropriate boundary conditions. The standard option is to prescribe head, $h\left(x_{\mathrm{s}}\right)=h_{\mathrm{s}}$, where $x_{\mathrm{s}}$ is the location of the sea boundary, which typically includes the sea bottom (top of the flow domain) and the aquifer edge (end of the flow domain), represented as a red line in Fig. 1.

This problem can be decomposed as the superposition of fluctuations due to the hydraulic response (boundary head fluctuations diffusing into the aquifer), $h_{\mathrm{H}}$, plus those caused by the mechanical perturbation (driven by the squeezing term fluctuations), $h_{\mathrm{M}}$ :

$h=h_{\mathrm{H}}+h_{\mathrm{M}}$

The hydraulic component represents head fluctuations driven by water flow from the sea boundary into the aquifer. It is governed by:
$S_{\mathrm{S}} \frac{\partial h_{\mathrm{H}}}{\partial t}=\nabla\left(K \nabla h_{\mathrm{H}}\right) ;$ subject to $h_{\mathrm{H}}\left(x_{\mathrm{s}}\right)=h_{\mathrm{s}}(t)$

Some insight into the nature of this equation can be gained from the traditional solution for a confined aquifer open at $x=$ 0 to a sea that fluctuates as $h_{\mathrm{s}}(t)=A_{\mathrm{s}} \sin (\omega t)$ at $x=0$. Note that $A_{\mathrm{s}}=r_{\mathrm{p}} A$, where $A$ is the amplitude of sea level fluctuations and $r_{\mathrm{p}}$ is the ratio of seawater to freshwater, which ensures that sea level fluctuations are expressed as freshwater head fluctuations. The solution to this problem under the approximation of Dupuit is (Ferris 1951):

$h_{\mathrm{H}}(x, t)=A_{\mathrm{s}} e^{-x / L_{\mathrm{c}}} \sin \left(\omega t-\frac{x}{L_{\mathrm{c}}}\right) ;$ with $L_{\mathrm{c}}=\sqrt{2 T / \omega S}$

where $A_{\mathrm{s}}$ is the amplitude of sea level fluctuations, $\omega$ is their frequency or angular velocity $\left(\mathrm{T}^{-1}\right)$ and $L_{\mathrm{c}}$ is the characteristic length. Note that the solution is written in terms of $S$, storage coefficient, and $T$, transmissivity of the aquifer. Actually, the solution depends solely on hydraulic diffusivity, $D_{\mathrm{h}}=T / S$, which is equal to $K / S_{\mathrm{s}}$ for a confined aquifer. Dependence of the response on hydraulic parameters becomes more complex in multiaquifer systems, separated by semiconfining layers. In these cases, head fluctuations in the aquifer are driven not only by the squeezing term in the aquifer, but also by flow from/to the aquitard. Guarracino et al. (2012) discuss the situation in detail.

The mechanical component represents head fluctuations driven by the squeezing of the medium caused by the load that the ocean exerts on the sea floor. It is governed by:

$$
\begin{aligned}
S_{\mathrm{S}} \frac{\partial h_{\mathrm{M}}}{\partial t} & =\nabla\left(K \nabla h_{\mathrm{M}}\right)+S_{\mathrm{S}} L_{\mathrm{e}} \frac{d h_{\mathrm{s}}}{d t} ; \text { subject to } h_{\mathrm{M}}\left(x_{\mathrm{s}}\right) \\
& =0
\end{aligned}
$$

Note that adding up Eqs. (3) and (5) yields Eq. (1), which demonstrates Eq. (2). Note also that the squeezing term is the sole source term in this equation. Therefore, the hydro-mechanical response, $h_{\mathrm{M}}$, is proportional to the time derivative of the sea level fluctuations under the portion of the aquifer subject to tidal loading (from the coastline to the offshore end of the aquifer)-that is, $S_{\mathrm{S}} L_{\mathrm{e}} d h_{\mathrm{S}} / d t=$ $S_{\mathrm{S}} L_{\mathrm{e}} A_{\mathrm{s}} \omega \cos (\omega t)$, which is proportional to the sea level frequency. Therefore, very low-frequency harmonics will tend to induce a very small mechanical effect in the aquifer, whereas high-frequency waves with higher derivatives should display a marked hydro-mechanical response; however, the effect is nontrivial. Far offshore in a homogeneous aquifer, where $h_{\mathrm{M}}$ gradients are small, the first term on the right-hand side of Eq. (5) can be neglected, which leads to $h_{\mathrm{M}} \cong L_{\mathrm{e}} h_{\mathrm{s}}$, regardless of $\omega$. In fact, the inland solution of Eq. (5) for a homogeneous perfectly confined aquifer reads (van der Kamp 1972). 
Fig. 1 Schematic description of aquifer geometry of a (semi)confined and an unconfined aquifer. Head is typically prescribed along all boundaries in contact with the sea (only along the coastline for unconfined aquifers under the Dupuit approximation). Hydro-mechanical response requires (some) confinement. The (semi)confined aquifer and the (semi)confining layer (aquitard) extend over a finite distance $D$ under the sea. The origin of hydraulic diffusion of both perturbations, hydraulic $\left(h_{\mathrm{H}}\right)$ and mechanical $\left(h_{\mathrm{M}}\right)$, is represented for the (semi)confined aquifer

$$
\begin{aligned}
h_{\mathrm{M}}(x, t) & =\frac{A_{\mathrm{s}} L_{\mathrm{e}}}{2} e^{-x / L_{\mathrm{c}}} \cos \left(\omega t-\frac{x}{L_{\mathrm{c}}}\right) ; \text { with } L_{\mathrm{c}} \\
& =\sqrt{2 T / \omega S}
\end{aligned}
$$

which is very similar to the hydraulic solution (Eq. 4), except that the amplitude is halved ( $L_{\mathrm{e}}$ is close to 1 for unconsolidated sediments) and the fluctuations are advanced $\pi / 2$ (i.e., a quarter of the period).

The fact that the source term in Eq. (5) is proportional to the time derivative of sea level fluctuations (and thus, to their frequency), together with the fact that the mechanical effect is instantaneous under the sea (actually it is transferred at speed of sound as a pressure wave) leads to complex interactions in the case of heterogeneity. Guarracino et al. (2012) analyse in detail the behaviour of both $h_{\mathrm{H}}$ and $h_{\mathrm{M}}$ for a broad range of conditions such as negligible and infinite extent of the aquifer under the sea, and for asymptotic limits of aquitard and aquifer parameters (rigid or stiff aquitard, confined or semiconfined aquifer).

\section{Inland propagation of harmonics depending on their different frequencies}

Both $h_{\mathrm{H}}$ and $h_{\mathrm{M}}$ diffuse hydraulically inland. Aquifer fluctuations are damped and delayed. For a confined aquifer (Eqs. 4 and 6), amplitude is damped by the factors $e^{-x / L_{\mathrm{c}}}$ for $h_{\mathrm{H}}$ and $0.5 e^{-x / L_{\mathrm{c}}}$ for $h_{\mathrm{M}}$, and the delay is $x / L_{\mathrm{c}}$ radians $\left(x / \omega L_{\mathrm{c}}\right.$ in time units). These two effects are somewhat different for semiconfined aquifers, where propagation is further damped (see solutions and discussion of Guarracino et al. (2012) and $\mathrm{Li}$ and Jiao (2003b)), but still the same for hydraulic and hydro-mechanical responses. So, the inland propagation of sea level fluctuations might look identical for hydraulic and hydro-mechanical responses (Fig. 2).

However, the origin of propagation of both perturbations, hydraulic and mechanical, is different and represented by the $x$ coordinate. The $x$ coordinate represents the distance to the coastline for hydro-mechanical response $(x=0 \mathrm{~m})$, but distance to the outlet for hydraulic response $(x=-D)$, as shown in Fig. 1. Since this distance can be a few kilometers, the aquifer response is likely to be damped and become negligible when $(x+D) / L_{\mathrm{c}}>3$ (Guarracino et al. 2012).

Both hydraulic and hydro-mechanical responses are delayed and their amplitudes damped depending on $\omega$ through the characteristic damping length, $L_{\mathrm{c}}$ (recall Eqs. 4 and 6). For high-frequency fluctuations, $\omega$ is large, so that the characteristic damping length is small (typically a few hundred meters), and fluctuations disappear close to the shore. The opposite occurs for low-frequency fluctuations, for which the characteristic distance can be a few kilometers. To support this fact, Table 1 contains the characteristic length for a range of frequencies and hydraulic diffusivities.

As a conclusion, when distance to the offshore connection to the sea $(D)$ is small, low-frequency harmonics of sea tides may produce a hydraulic response far inland in the aquifer, while high-frequency harmonics will not, which lends some hope to analyzing connectivity to the sea by considering response to diverse harmonics.

\section{Data processing for extracting low-frequency components}

Tidal response methods require records of the time evolution of aquifer heads and sea level. Data records should be long enough in time to capture very low-frequency fluctuations (around months) responsible for hydraulic response. 
Fig. 2 Relation between amplitudes of hydraulic, $A_{\mathrm{H}}$, and hydro-mechanical, $A_{\mathrm{M}}$, responses to tidal amplitude, $A_{\mathrm{S}}$, into a hypothetical confined aquifer ( $\mathrm{T}=20 \mathrm{~m} /$ day: $\mathrm{S}=0.0001)$ to high-frequency $(\omega=12.6 \mathrm{rad} /$ day or period $\left.12 \mathrm{~h}, \mathrm{~L}_{\mathrm{c}}=179 \mathrm{~m}\right)$ and low-frequency $(\omega=0.21 \mathrm{rad} /$ day or period 1 month, $L_{\mathrm{c}}=1,382 \mathrm{~m}$ ) harmonics. Diffusion into the aquifer is identical, when properly scaled (hydro-mechanical amplitude is about half of the hydraulic amplitude, Eq. (6), except that distance is measured from the shoreline $(x)$ for the hydromechanical response, but from the offshore aquifer outlet $(x+D)$ for the hydraulic response

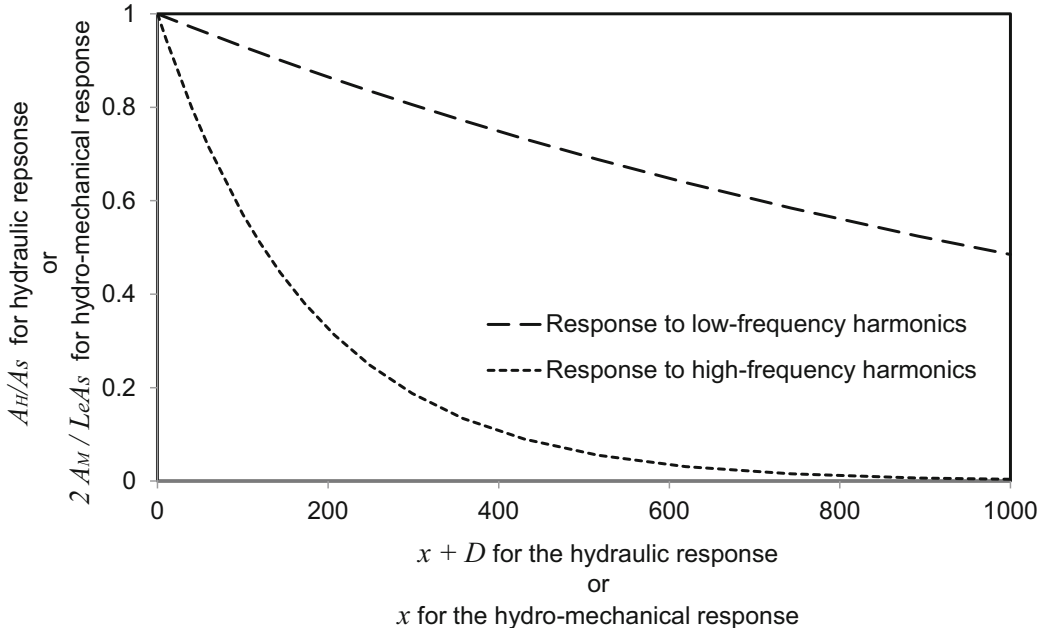

This study proposed to analyze the aquifer response to lowfrequency components of sea tides. To decompose both the tidal and head fluctuation time series, the method described by Hsieh et al. (1987) is applied, who attribute it to Godin (1972). This method is more robust and less sensitive to the record length than the more traditional Fournier method. Godin's method is based on the sequential application of moving averages with windows of specific length according to the period of interest, $\tau$. Then, $\mathcal{A}_{\tau, n} / n$ is the average of $n$ consecutive data points comprising a time length equal to $\tau$ (e.g., for 10min interval data, a period of $1 \mathrm{~h}$ requires averaging six sequential data points, $n=6$ ). The resulting average is applied to the mid-time of the averaged interval (i.e., measurement times are averaged as the measurements). It should be noted that the average window is reduced at the edges of the interval, so that the moving average is unreliable for an interval of half of the averaging window at the beginning and end of the record. Godin's method consists of applying sequentially the aforementioned average according to:

$\zeta(\tau)=\mathcal{A}_{\tau, n}^{2} \mathcal{A}_{\tau, n+1} /\left[n^{2}(n+1)\right]$

This expression requires three sequential averaging operations, two with a window of $n$ data points, and one with $n+1$. Godin's operator, $\zeta(\tau)$, removes those components with periods shorter than $\tau$. Then, the result of applying $\zeta(\tau)$ is the smoothed time series containing those components with periods equal or greater than $\tau, \zeta(\tau)=h_{\geq \tau}(t)$, where the subscript
Table 1 Characteristic damping length (m) for ranges of periods/ frequencies and hydraulic diffusivity

\begin{tabular}{lllllll}
\hline Frequency (L/day) & Period (days) & \multicolumn{5}{l}{ Hydraulic diffusivity (m²/day) } \\
\cline { 3 - 7 } & & $1.00 \mathrm{E}+07$ & $1.00 \mathrm{E}+06$ & $1.00 \mathrm{E}+05$ & $1.00 \mathrm{E}+04$ & $1.00 \mathrm{E}+03$ \\
\hline 0.15 & 42 & 11,562 & 3,656 & 1,156 & 366 & 116 \\
0.18 & 35 & 10,555 & 3,338 & 1,056 & 334 & 106 \\
0.224 & 28 & 9,441 & 2,985 & 944 & 299 & 94 \\
0.299 & 21 & 8,176 & 2,585 & 818 & 259 & 82 \\
0.449 & 14 & 6,676 & 2,111 & 668 & 211 & 67 \\
0.898 & 7 & 4,720 & 1,493 & 472 & 149 & 47 \\
1.257 & 5 & 3,989 & 1,262 & 399 & 126 & 40 \\
2.094 & 3 & 3,090 & 977 & 309 & 98 & 31 \\
6.283 & 1 & 1,784 & 564 & 178 & 56 & 18 \\
12.57 & 0.5 & 1,262 & 399 & 126 & 40 & 13 \\
\hline
\end{tabular}


denotes the periods of the components. Specifically, if a signal consists of $m$ harmonics of sequential periods, where $\tau_{1}>\tau_{m}$, this signal can be decomposed as:

$h(t)=h_{\tau 1}(t)+h_{\tau 2}(t)+h_{\tau 3}(t)+\ldots+h_{\tau m}(t)$

After applying Godin's operator to $h(t)$ for $\tau_{2}$, the spectrum of components with periods equal or larger than $\tau_{2}$ is obtained:

$\zeta\left(\tau_{2}\right)=h_{\geq \tau 2}(t)=h_{\tau 1}(t)+h_{\tau 2}(t)$

The spectrum of components with periods shorter than $\tau_{2}$ can be calculated by subtracting the smoothed records from the signal. So, the spectrum of components with periods shorter than $\tau_{2}$ can be obtained as:

$h_{<\tau 2}(t)=h(t)-\zeta\left(\tau_{2}\right)=h_{\tau 3}(t)+\ldots+h_{\tau m}(t)$

To obtain a specific interval of components from a signal (e.g. period interval between $\tau_{2}$ and $\tau_{m-1}$, where $\tau_{2}>\tau_{m-1}$ ), the Godin operator is applied first for $\tau_{2}$ over the signal, $\zeta\left(\tau_{2}\right)$ as in Eq. (9). Then, the spectrum of components with periods shorter than $\tau_{2}$ are obtained by subtracting $\zeta\left(\tau_{2}\right)$ from the signal as in Eq. (10). Finally, the Godin operator is applied again for $\tau_{m-1}$ over $h_{<\tau 2}(t)$, the spectrum of components with periods shorter than $\tau_{2}$. This last step yields records that contain the tidal components of periods between $\tau_{2}$ and $\tau_{m-1}$.

$\zeta\left(\tau_{m-1}\right)=h_{\geq \tau m-1}(t)=h_{\tau 3}(t)+\ldots+h_{\tau m-1}(t)$

\section{Practical recommendations}

Actual application of the proposed method is relatively simple; however, judgment is required to select the frequencies that indicate hydraulic connection. Also, head fluctuations driven by causes other than sea level fluctuations (e.g., rainfall, pumping, etc.) need to be discarded. To this end, the following recommendations are suggested:

1. The amplitude factors of hydraulic and hydro-mechanical response according to Eqs. (4) and (6) are $e^{-x / L_{\mathrm{c}}}$ and 0.5 $e^{-x / L_{\mathrm{c}}}$ for $h_{\mathrm{H}}$ and $h_{\mathrm{M}}$ respectively. These factors are close to 1 and 0.5 when $x \ll L_{\mathrm{c}}$. If the observed amplitude of a specific frequency component of aquifer heads is greater than half the tidal amplitude for the same frequency component, it can be assumed that this component represents a hydraulic response. According to Eq. (6), the hydromechanical response is cut in half from the coastline towards inland and the phase shift should be negativecosine function in Eq. (6) advances the response a quarter of the period. Therefore, head records with amplitudes greater than half of sea tidal amplitudes and evident phase shifts, can be assumed as hydraulic responses, whereas head records with significant damping (i.e. amplitude less than half that of the sea), but small (or even negative) phase shift are likely to represent hydro-mechanical response.

2. Other external factors such as pumping or recharge fluctuations, have to be dismissed to ensure that observed aquifer head fluctuations are indeed induced by sea level fluctuations. This can be done by comparing the frequency components of aquifer heads and sea level. If these components are similar (i.e., the aquifer signal is damped and delayed with respect to the sea signal), it is likely that the aquifer signal is indeed driven by sea level fluctuations. Otherwise (e.g., higher amplitude of the aquifer fluctuation during some intervals of time), then those intervals or the whole component should be discarded for the analysis.

3. Finally, it should be noted that when applying Godin's method, the first and last intervals of averages do not fully represent the trend. The length of these intervals is the same as the average window. Very low-frequency components imply longer average windows. Therefore, a compromise solution between the selected frequency and the length of data records should be adopted in order to ensure a trustworthy representation of trends.

\section{Application}

\section{Geological, hydrogeological and meteorological settings}

The proposed methodology was applied in the coastal aquifer system of La Plata River Estuary (LPRE) to qualitatively evaluate the hydraulic connection of its aquifers. The study site is located in the Matanza-Riachuelo river basin (MRB), south of Buenos Aires city in the municipality of Avellaneda $\left(34.66^{\circ} \mathrm{S}\right.$, $58.31^{\circ} \mathrm{W}$; Fig. 3a). The basin management authority (Autoridad de Cuenca Matanza-Riachuelo, ACUMAR) drilled several boreholes in this area next to the sea in order to monitor the aquifer system of this river basin.

It is a sedimentary basin filled with continental and marine sediments deposited over the basement. Overlapping the basement there is the Olivos Formation, a continental formation of aeolian and fluvial origin (Auge 1986, 2004). The OlivosFormation is covered by the marine Paraná formation. It is sandy to the bottom and clayey to the top. Over the Paraná formation there is the Puelches formation, mostly fluvial but with some aeolian components (Logan et al. 1999). Clay abundance increases toward the top. On top of the Puelches formation there are the Pampeano sediments (Fidalgo et al. 1975), mostly of eolian origin but with fluvial and lacustrine deposits. The aeolian fraction consists of sandy silts and loess with a volcanic (Andean) origin (González Bonorino 1965; 
Fig. 3 a Location of the study site in Matanza Riachuelo Basin (MRB), La Plata River Estuary (LPRE). b Conceptualization of geological and hydrogeological formations from the study site and location of the two monitoring wells a

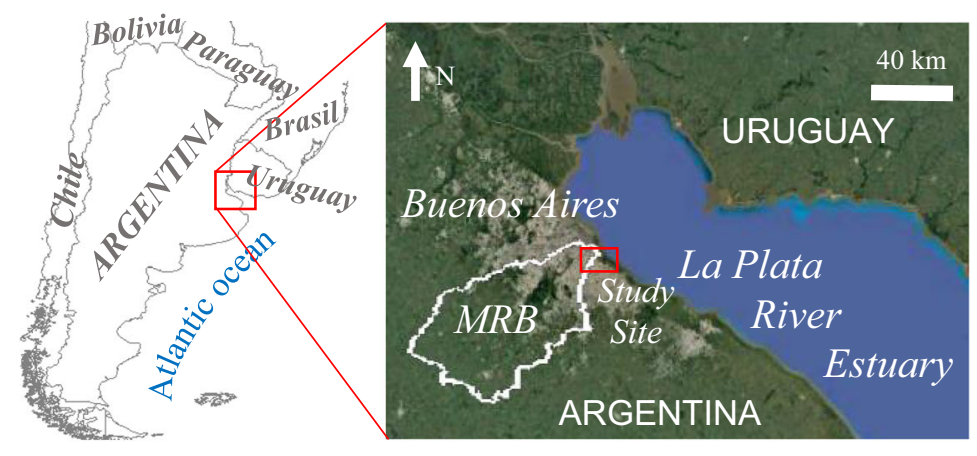

b

Tidal loading

Coastline

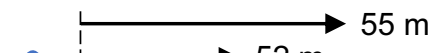

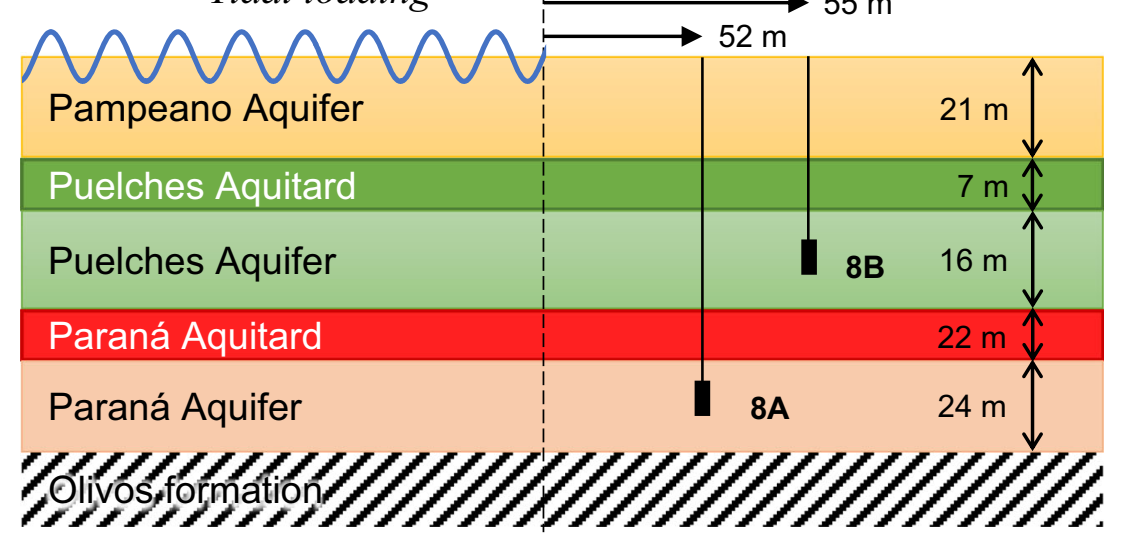

Tófalo et al. 2005). These sediments cover an extended area in NE Argentina, forming the large plain area called La Pampa.

Three aquifers have been described in the study site. They are related to the uppermost aforementioned geological layers: the Paraná aquifer, the Puelches aquifer (both confined aquifers) and the Pampeano aquifer, which is an unconfined aquifer (Fig. 3b). The aquitard between the Pampeano and Puelches aquifers appears at 21-28 $\mathrm{m}$ depth in the study area. The top of the Paraná Formation is some $44 \mathrm{~m}$ deep at the site (Mancino et al. 2013) as shown in Fig. 3b. The existing groundwater models agree that there is a regional flow that discharges to La Plata river estuary (Vives et al. 2013; Zabala et al. 2016).

Wind is one of the main stressors of low-frequency tides in LPRE (Santoro et al. 2011). The wind pattern in LPRE has been widely studied, showing a seasonal trend in its direction and velocity (Guerrero et al. 1997; Simionato et al. 2005). During summer time, onshore winds from $\mathrm{NE}, \mathrm{E}, \mathrm{SE}$ and $\mathrm{S}$ are prevalent, which act to pile up river water. In extreme cases, strong south-easterly winds, locally called sudestadas, induce high tides during 1-3 days. According to the statistical analysis in Escobar et al. (2004), sudestadas are more frequent in summer. During this phenomenon, the water level rises and floods Buenos Aires city and surroundings.

\section{Data description}

Two monitoring wells record hydraulic heads. The first is open in the Puelches aquifer, $55 \mathrm{~m}$ from the coast. The second one monitors the Paraná aquifer, $52 \mathrm{~m}$ from the coast (Fig. 3b). The sensors collected data every hour from 12 March 2015 to 23 June 2015. The data have been corrected according to the atmospheric pressure of a barometer. Sea level records from tide gauges in the San Fernando (34 ${ }^{\circ} 26^{\prime} 03^{\prime \prime}$ S 58 $\left.32^{\prime} 24^{\prime \prime} \mathrm{W}\right)$ and Puerto Buenos Aires (34³3'39" S 58.23'56" W) stations were obtained from the Naval Hydrography service of the Ministry of Defense of Argentina. The three sets of records (sea level, heads in piezometers $8 \mathrm{~A}$ and $8 \mathrm{~B}-$ see Fig. $3 \mathrm{~b}$ ) were transformed to fluctuations around the mean value of the interval.

The data used in this study are displayed in Fig. 4. The records in Puelches and Paraná aquifers show a clear hydromechanical response to semidiurnal fluctuations. Aquifer fluctuations are hardly delayed with respect to tidal fluctuations, but their amplitude is about one third of the tidal amplitude. The fact that Puelches and Paraná aquifers show a hydromechanical response suggests that both aquifers are poorly connected to the sea. However, it is not clear whether there is any connection at all, and if so, which one of them, Puelches or Paraná, could be better hydraulically connected to the sea. 
Fig. 4 Observed fluctuations of sea tide and piezometers $8 \mathrm{~A}$ (Paraná aquifer) and 8B (Puelches aquifer)

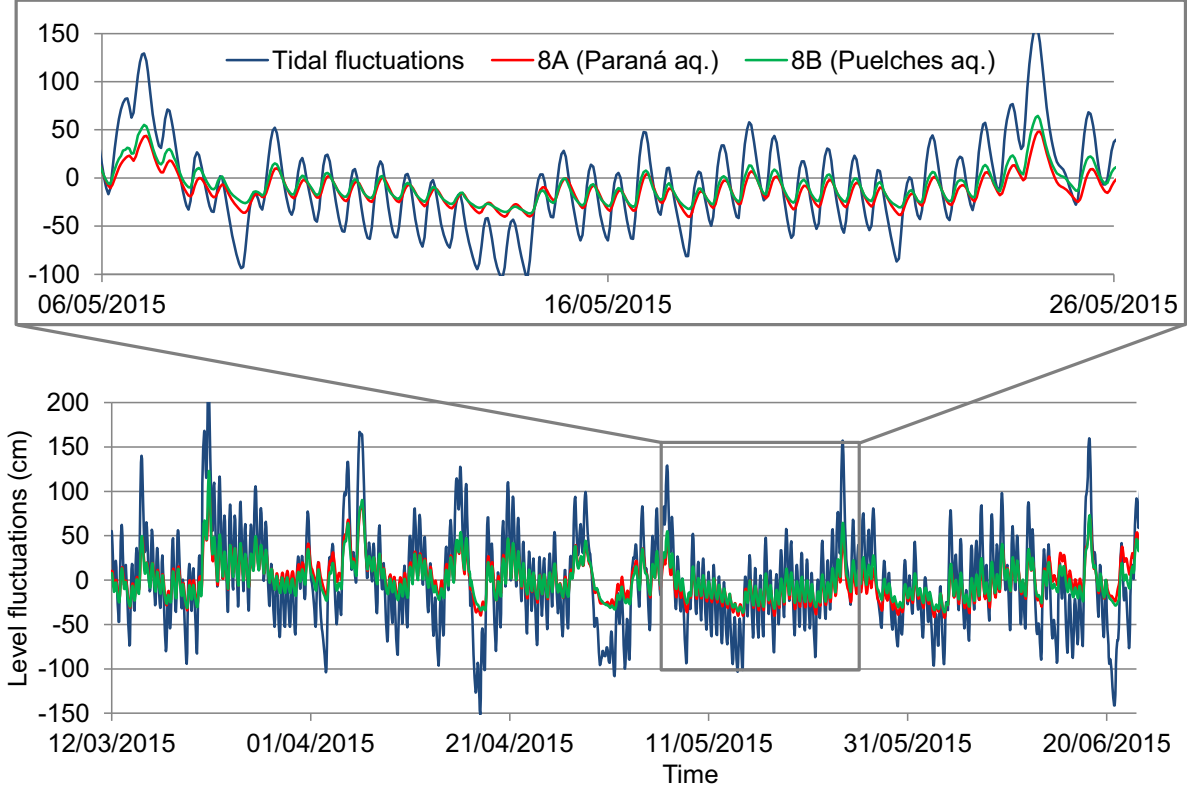

No additional effects are thought to be influencing the groundwater level: recharge episodes are difficult to observe in confined aquifers and there are no human activities requiring groundwater pumping nearby, as the study site is located in a natural area without urbanization or farming.

\section{Data processing}

In order to select a representative low-frequency component, Godin's method was applied to decompose sea level and head fluctuations (application of Godin's methods is explained more in detail later for the selected frequency component). The decomposition into the spectrum of components is shown in Fig. 5.

The amplitudes of each component were analyzed and the amplitude coefficients (ratio between tidal and head amplitudes) were calculated and tabulated in Table 2. As can be seen in Fig. 5, the data series are not long enough to get representative harmonics for very low frequencies, so periods longer than 5 weeks are dismissed. Therefore, this analysis must be considered qualitative.

The high-frequency components (periods less than 2 weeks) are clearly hydro-mechanical: the piezometric amplitudes are less than half the tide amplitudes and the phase shift is negative at some cycles, although the average value is positive. Further support for this assessment can be gained from the fact that amplitude ratio, which is proportional to $e^{-x / L_{\mathrm{c}}}$, tends to increase with the period of the component, because $L_{\mathrm{c}}$ also increases.
Among the low-frequency components, the most representative is the component with periods between 5 and 4 weeks, which captures a consecutive maximum and minimum and the piezometric responses reflect the tide behavior. It is worth noting that the amplitudes of Paraná aquifer are greater than amplitudes of Puelches aquifer for the whole spectrum of low-frequency components. This contrasts with the high-frequency components, which show similar amplitude coefficients; in some cases (for periods 7-5 days and 3-2 days), the amplitude is greater for Puelches aquifer, the rest being equal. This fact reveals the heterogeneity of the geological media offshore.

A description on how to obtain the component of period between 5 and 4 weeks is detailed next. For each of the three data sets, a total of three steps must be performed. The results of each step are shown in Fig. 6. First, Godin's operator is applied for a period of 5 weeks, $\zeta\left(\tau_{5}\right)$, over the raw data. As raw data are hourly spaced, there are 840 data records in a time length equal to 5 weeks:

$\zeta\left(\tau_{5}\right)=h_{\geq 5}=\mathcal{A}_{5,840}^{2} \mathcal{A}_{5,841} /\left[840^{2}(841)\right]$

where $h_{\geq 5}$ is the portion of the original record containing periods equal to or greater than 5 weeks. Second, the spectrum of components with periods smaller than 5 weeks, $h_{<5}$, is obtained by removing $h_{\geq 5}$ from the raw data:

$h_{<5}=h(t)-h_{\geq 5}=h(t)-\zeta\left(\tau_{5}\right)$

Finally, Godin's operator is applied again over $h_{<5}$ for a period of 4 weeks. As a result, the spectrum of components 
— Sea tide — Puelches aq. — Paraná aq.
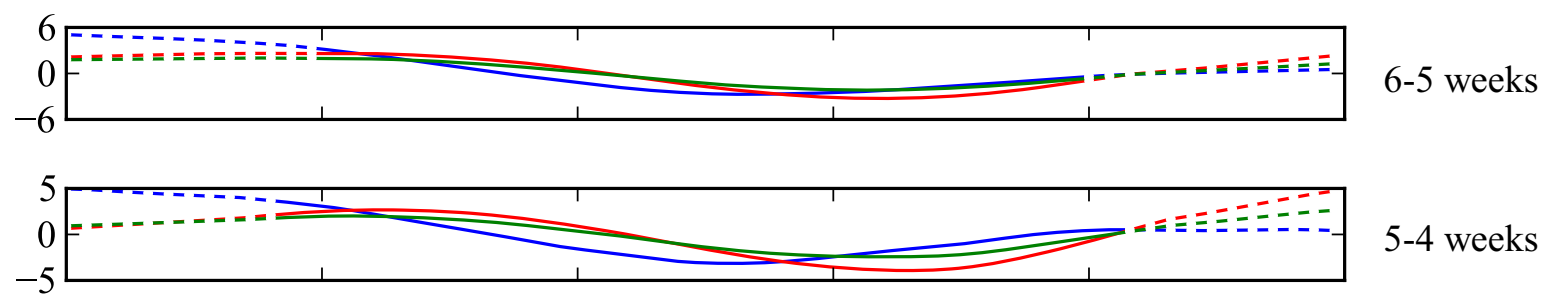

5-4 weeks

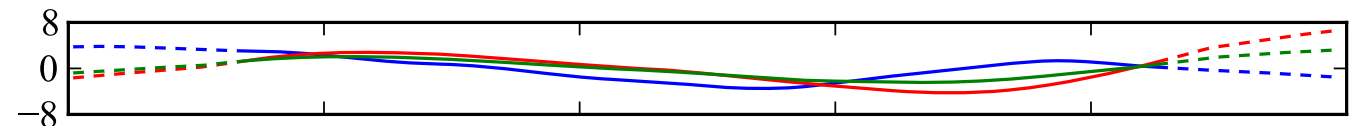

4-3 weeks

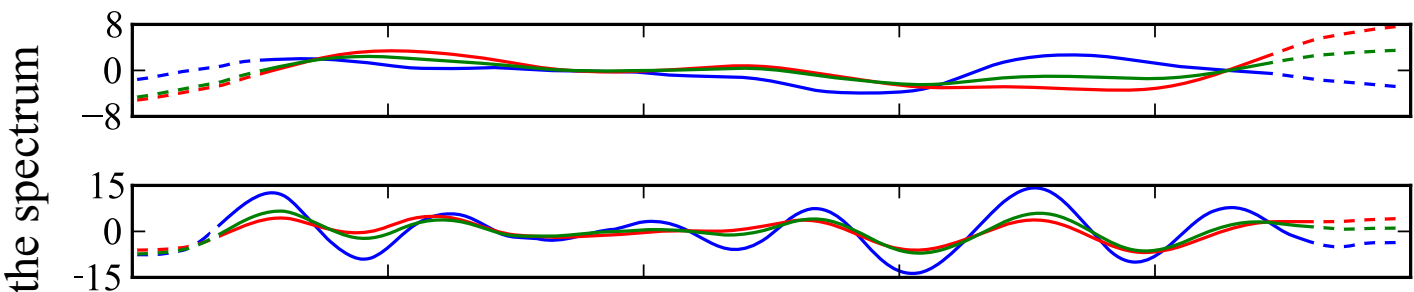

3-2 weeks

\section{2-1 weeks}

○一

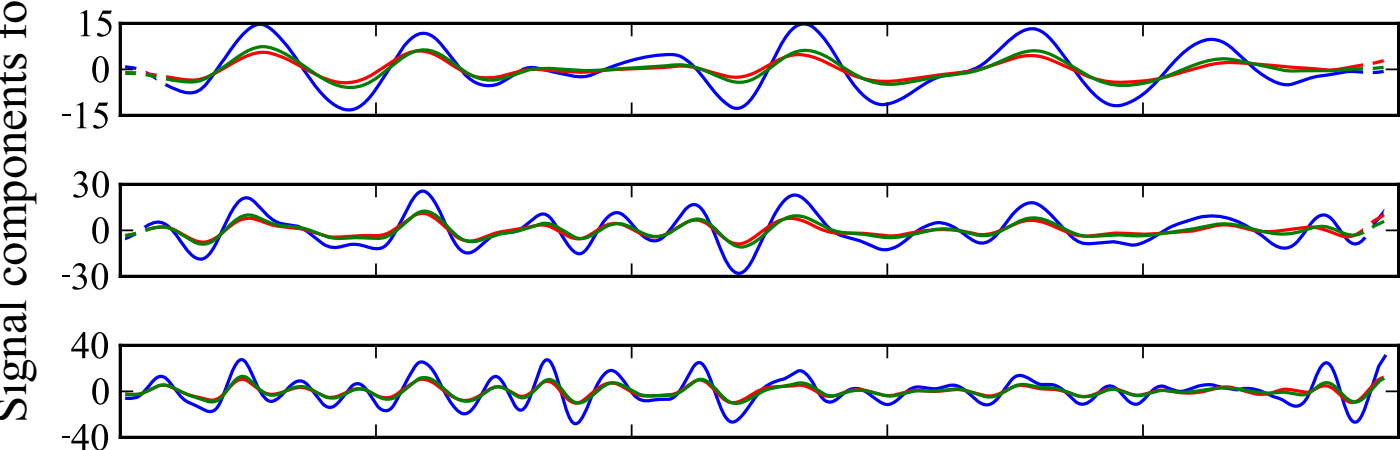

7-5 days

\section{5-3 days}

3-2 days

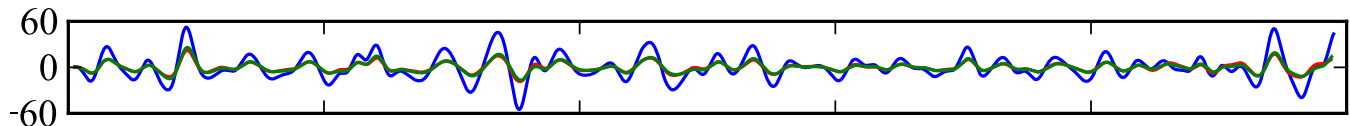

2-1 days

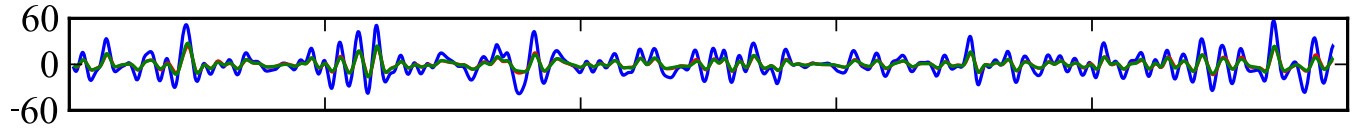

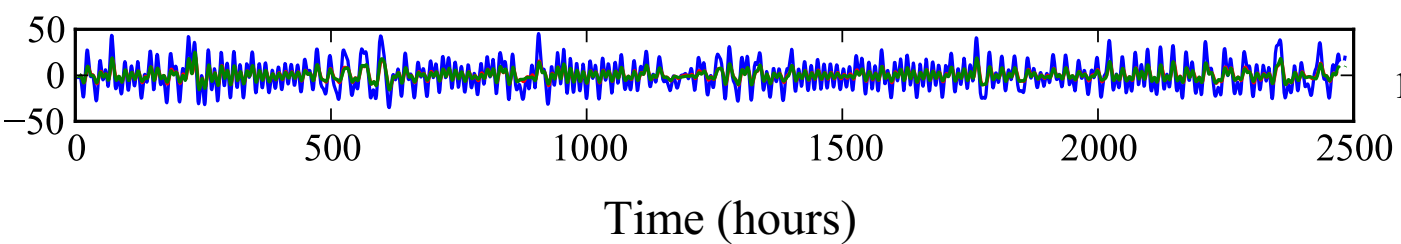

12-6 hours

Fig. 5 Decomposition of signals into the spectrum of components for several periods (6-5 weeks, 5-4 weeks, 4-3 weeks, 3-2 weeks, 21 weeks, 7-5 days, 5-3 days, 3-2 days, 2-1 days, 24-12 h, 12-6 h).
The lines are dashed for the initial and final intervals, which are uncertain because of the average window 
Table 2 Average values of amplitude ratio and phase shifts between piezometric heads in Paraná (8A) and Puelches (8B) aquifer to sea tides

\begin{tabular}{llllll}
\hline Period & \multicolumn{2}{l}{ Amplitude ratio } & & \multicolumn{2}{l}{ Phase shift (hours) } \\
\cline { 2 - 3 } \cline { 6 - 6 } & Piez. 8A & Piez. 8B & & Piez. 8A & Piez. 8B \\
\hline 6-5 weeks & 0.76 & 0.54 & & 253 & 238 \\
5-4 weeks & 0.81 & 0.55 & & 345 & 295 \\
4-3 weeks & 0.96 & 0.61 & & 370 & 313 \\
3-2 weeks & 0.87 & 0.72 & & 494 & 545 \\
2-1 weeks & 0.46 & 0.50 & & 10 & 6 \\
7-5 days & 0.37 & 0.38 & & 8 & -1 \\
5-3 days & 0.29 & 0.34 & & 0 & 5 \\
3-2 days & 0.37 & 0.40 & & 6 & 8 \\
2-1 days & 0.39 & 0.39 & & 2 \\
24-12 h & 0.36 & 0.35 & 2 & 1 \\
12-6 h & 0.33 & 0.33 & & 1 \\
\hline
\end{tabular}

with periods between 5 and 4 weeks is obtained:

$$
\zeta\left(\tau_{4}\right)=h_{5>\tau \geq 4}=\mathcal{A}_{4,672}^{2} \mathcal{A}_{4,673} /\left[672^{2}(673)\right]
$$

\section{Results and discussion}

The responses of each aquifer were analyzed by comparing the head components in the 4-5-week-period interval. Amplitudes are assimilated to the head differences between a maximum and the next minimum. The amplitude of the deepest Paraná aquifer is greater $(6.6 \mathrm{~cm})$ than the amplitude of the hydraulic response in the overlaying Puelches aquifer $(4.5 \mathrm{~cm})$ (Fig. 7). The fact that the amplitude observed in the Puelches is more damped than that in the Paraná reveals that the Paraná aquifer would be better connected to La Plata estuary than the Puelches.

This finding is somewhat surprising because one would expect that the Paraná aquifer, being deeper, would be less connected to the sea than the Puelches. Actually, a geological analysis shows that this is possible. The records of the Puelches aquifer thickness in inland boreholes indicate that the Puelches aquifer wedges towards the sea (Mancino et al. 2013). If the trend continues, the Puelches aquifer could disappear offshore, as illustrated in Fig. 8. Alternatively, the hydraulic diffusivity of Puelches aquifer could just decrease offshore (by a decrease of hydraulic conductivity or increase of storage coefficient offshore). This option could also be valid according to sequential stratigraphy principles, if it is assumed
Fig. 6 Raw data and results from each step of processing: step 1 , smoothed records with periods greater than 5 weeks; step 2 , spectrum of components with periods smaller than 5 weeks; step 3 , interval of components with periods between 5 and 4 weeks

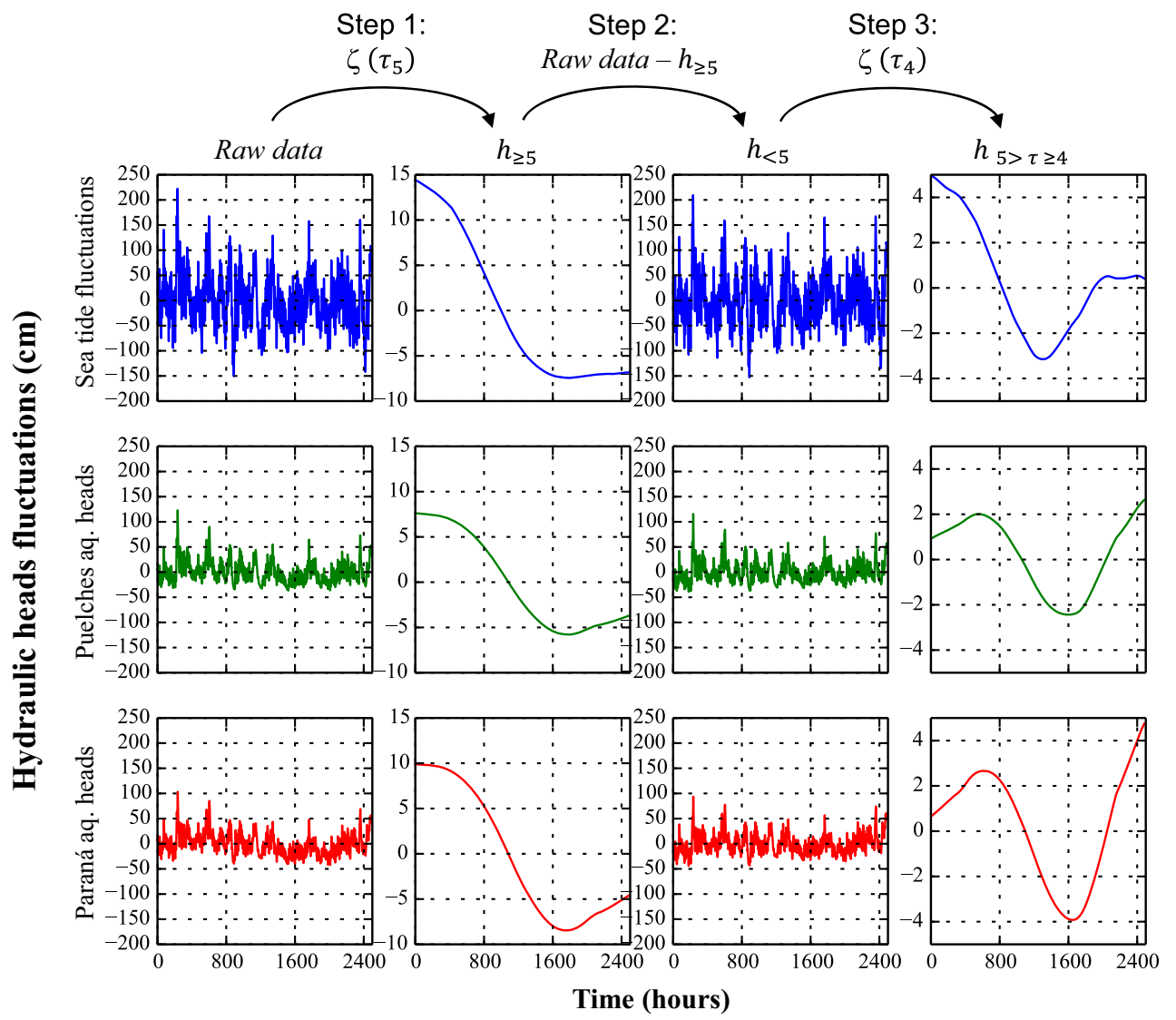


Fig. 7 Head components in the low-frequency interval, between 5 and 4-week period, of the sea tide and Paraná and Puelches aquifers

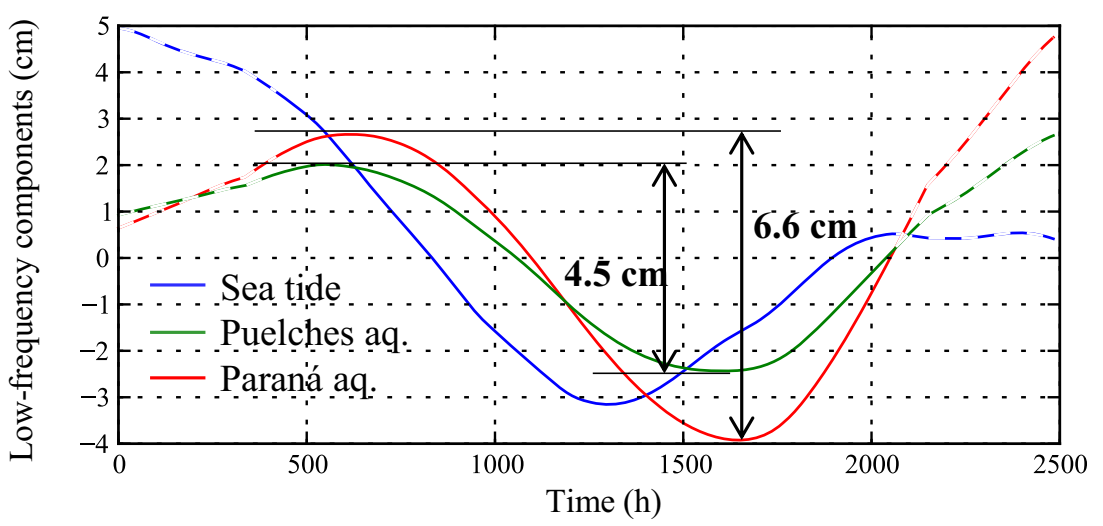

that coarse particles are deposited next to the coastline and the finest, offshore.

The phase shift for Puelches aquifer is slightly smaller (12.3 days) than for Paraná aquifer (14.4 days), which would contradict the amplitude finding if the response was purely hydraulic and the aquifers perfectly confined. In general, the interpretation of phase shifts is complicated by interference with the hydro-mechanical response and by leakage from/to aquitard. The quantitative joint interpretation of amplitudes and phase shift is very complex, because of the influence of both aquifer and aquitard properties. Instead, amplitudes typically display a more consistent response.

\section{Conclusions}

A methodology to isolate the hydraulic from the hydromechanical response in coastal aquifers was developed in order to characterize the hydraulic connection of different wells to the sea. It is based on the different aquifer responses to low and high-frequency components of sea tides. High-frequency components in semiconfined aquifers can be attributed to hydro-mechanical response, whereas low-frequency components contain information about hydraulic connection. Therefore, the harmonic decomposition of aquifer head and sea level fluctuations is useful to qualitatively analyze the hydraulic connection of coastal aquifers to the sea. This is the first attempt to apply the harmonic decomposition of aquifer heads to analyze the hydraulic connection of the aquifer to the sea.

Fig. 8 Hypothesis for geological setup of aquifers under the sea in LPRE: a wedging of Puelches aquifer; $\mathbf{b}$ gradual reduction of Puelches aquifer granulometry
When using tidal loading for characterizing coastal aquifers, the different frequencies of the tide signal test different extensions of the aquifer because the characteristic damping length depends on the frequency. High-frequency components would be equivalent to quick pumping tests where only a small portion of the aquifer is tested. Low-frequency waves give information on larger areas of the aquifer, because these waves are damped only at larger distances. As a consequence, the response to low-frequency components of sea-level fluctuations yields information about the hydraulic diffusivity offshore.

The methodology was applied to the aquifer system of La Plata River Estuary. The comparison of the aquifers' responses to low-frequency tidal harmonics suggests that the deeper Paraná aquifer appears to be slightly better connected to the sea than the upper Puelches aquifer. While this result might look surprising, it can be explained on the basis of geological information.

The methodology is powerful and useful. Still, it must be clarified that groundwater observations in coastal aquifers can be affected by numerous factors. Aquifer heads reflect not only the response to tidal variations, but also the natural trend of the aquifer inland, such as recharge variations or pumping. The superposition of these effects often complicates the interpretation of coastal aquifer head records. An advantage of the proposed methodology is that it separates the various head components according to their frequency. This should facilitate identifying which components are shared by the sea level and aquifer records, but does not eliminate the need to identify the response to other phenomena apart from tides.
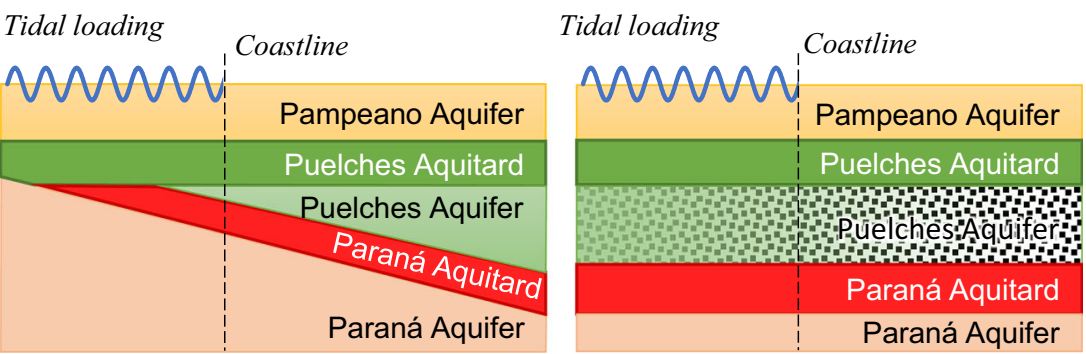
Ideally, the time series should be long enough to catch at least a complete wave cycle in sea tides and piezometric level. If available, a quantitative rather than the qualitative conclusion presented here about the hydraulic connectivity could be done.

Acknowledgements The authors wish to acknowledge the MatanzaRiachuelo Autorithy Basin (ACUMAR) for providing the aquifer data. We would like to thank the anonymous reviewers for their constructive comments which greatly improved this manuscript.

Funding The first author was funded by the National Scientific and Technical Research Council of Argentina (CONICET).

\section{References}

Ahring A, Kothe M, Gattke C, Christoffels E, Diekkrüger B, Ahring A, Kothe M, Gattke C, Christoffels E, Diekkrüger B (2020) Combining ecohydrological catchment modelling and water quality monitoring to assess surface water pollution in the Swist River Basin. 22nd EGU General Assembly, Vienna, 4-8 May, 2020, 19842. https:// ui.adsabs.harvard.edu/abs/2020EGUGA..2219842A/abstract. Accessed March 2021

Alvarez O, Gomez-Velez JD, Brown K, Kosson D, Burger J, Gochfeld M, Stewart J, Stweart R, Alvarez O, Gomez-Velez JD, Brown K, Kosson D, Burger J, Gochfeld M, Stewart J, Stweart R (2019) Assessing risk in groundwater contaminated sites: the importance of preserving subsurface connectivity and integrating multiple data sources. American Geophysical Union, Fall Meeting, San Francisco, 2019, H13B-07. https://ui.adsabs.harvard.edu/abs/ 2019AGUFM.H13B..07A/abstract. Accessed March 2021

Asadi-Aghbolaghi M, Chuang MH, Der Yeh H (2014) Groundwater response to tidal fluctuation in an inhomogeneous coastal aquiferaquitard system. Water Resour Manag 28(11):3591-3617. https:// doi.org/10.1007/s11269-014-0689-9

Auge M (1986) Hydrodynamic behavior of the Puelche Aquifer in Matanza River Basin. Groundwater 25(5):636-642

Auge M (2004) Hidrogeología de la ciudad de Buenos Aires. Universidad Nacional de Buenos Aires Available at: http://tierra.rediris.es/ hidrored/ebooks/miguel/HidrogeoBsAS.pdf. Accessed 1 April 2015

Bear J, Cheng AH-D, Sorek S, Ouazar D, Herrera I (eds) (1999) Seawater intrusion in coastal aquifers: concepts, methods and practices. Theory and Applications of Transport in Porous Media. Springer, Heidelberg, Germany. https://doi.org/10.1007/978-94-017-2969-7

Bianchi M, Zheng C, Wilson C, Tick GR, Liu G, Gorelick SM (2011) Spatial connectivity in a highly heterogeneous aquifer: from cores to preferential flow paths. Water Resour Res 47(5). https://doi.org/10. 1029/2009WR008966

Bredehoeft JD (1967) Response of well-aquifer systems to Earth tides. J Geophys Res 72(12):3075-3087

Chuang MH, Der Yeh H (2011) A generalized solution for groundwater head fluctuation in a tidal leaky aquifer system. J Earth Syst Sci 120(6):1055-1066. https://doi.org/10.1007/s12040-011-0128-8

Cuello JE, Guarracino L, Monachesi LB (2017) Groundwater response to tidal fluctuations in wedge-shaped confined aquifers. Hydrogeol J 25(5):1509-1515. https://doi.org/10.1007/s10040-017-1579-z

Escobar G, Vargas W, Bischoff S (2004) Wind tides in the Rio de la Plata estuary: meteorological conditions. Int J Climatol 24(9):1159-1169. https://doi.org/10.1002/joc. 1026

Fadili A, Malaurent P, Najib S, Mehdi K, Riss J, Makan A, Boutayeb K (2016) Investigation of groundwater behavior in response to oceanic tide and hydrodynamic assessment of coastal aquifers. Environ Monitor Assess 188(5). https://doi.org/10.1007/s10661-016-5287-2

Ferris JG (1951) Cyclic fluctuations of water level as a basis for determining aquifer transmissibility. Assembly of the International Union of Geodesy and Geophysics, Brussels, August 1951

Fidalgo F, De Francesco FO, Pascual R (1975) Geología superficial de la llanura bonaerense (Argentina). VI Congreso Geológico Argentino. Bahía Blanca pp. 103-138

Geng X, Li H, Boufadel MC, Liu S (2009) Tide-induced head fluctuations in a coastal aquifer: Effects of the elastic storage and leakage of the submarine outlet-capping. Hydrogeol J 17(5):1289-1296. https://doi.org/10.1007/s10040-009-0439-x

Giudici M, Margiotta S, Mazzone F, Negri S, Vassena C (2012) Modelling hydrostratigraphy and groundwater flow of a fractured and karst aquifer in a Mediterranean basin (Salento peninsula, southeastern Italy). Environ Earth Sci 67(7):1891-1907. https://doi.org/ $10.1007 / \mathrm{s} 12665-012-1631-1$

Godin G (1972) The analysis of tides. University of Toronto Press, Toronto

González Bonorino F (1965) Mineralogía de las fracciones arcilla y limo del Pampeano en el área de la ciudad de Buenos Aires y su significado estratigráfico y sedimentológico. Rev Asoc Geol Argent 20(1):67-148

Guarracino L, Carrera J, Vázquez-Suñé E (2012) Analytical study of hydraulic and mechanical effects on tide-induced head fluctuation in a coastal aquifer system that extends under the sea. J Hydrol 450 451:150-158. https://doi.org/10.1016/j.jhydrol.2012.05.015

Guerrero RA, Acha EM, Framiñan MB, Lastra CA (1997) Physical oceanography of the Rio de la Plata Estuary, Argentina. Continental Shelf Res 17(7):727-742

He Z, Han D, Song X, Yang S (2020) Impact of human activities on coastal groundwater pollution in the Yang-Dai River plain, northern China. Environ Sci Pollut Res 1-22. https://doi.org/10.1007/ s11356-020-09760-7

Hsieh PA, Bredehoeft JD, Farr JM (1987) Determination of aquifer transmissivity from Earth tide analysis. Water Resour Res 23(10):1824 1832. https://doi.org/10.1029/WR023i010p01824

Hsieh PC, Hsu HT, Liao CB, Te Chiueh P (2015) Groundwater response to tidal fluctuation and rainfall in a coastal aquifer. J Hydrol 521: 132-140. https://doi.org/10.1016/j.jhydrol.2014.11.069

Jacob CE (1940) On the flow of water in an elastic artesian aquifer. Trans Am Geophys Union 21(2):574-586. https://doi.org/10.1029/ TR021i002p00574

Jha MK, Namgial D, Kamii Y, Peiffer S (2008) Hydraulic parameters of coastal aquifer systems by direct methods and an extended tideaquifer interaction technique. Water Resour Manag 22(12):1899 1923. https://doi.org/10.1007/s11269-008-9259-3

Jiao JJ, Tang Z (1999) An analytical solution of groundwater response to tidal fluctuation in a leaky confined aquifer. Water Resour Res 35(3):747-751

Knight JH, Rassam DW (2007) Groundwater head responses due to random stream stage fluctuations using basis splines. Water Resour Res 43(May 2006):2-7. https://doi.org/10.1029/2006WR005155

Knudby C, Carrera J (2005) On the relationship between indicators of geostatistical, flow and transport connectivity. Adv Water Resour 28(4):405-421. https://doi.org/10.1016/j.advwatres.2004.09.001

Knudby C, Carrera J (2006) On the use of apparent hydraulic diffusivity as an indicator of connectivity. J Hydrol 329:377-389. https://doi. org/10.1016/j.jhydrol.2006.02.026

Li H, Jiao JJ (2001) Tide-induced groundwater fluctuation in a coastal leaky confined aquifer system extending under the sea. Water Resour Res 37(5):1165-1171

Li H, Jiao JJ (2003a) Review of analytical studies of tidal groundwater flow in coastal aquifer systems. Water Resour Urban Environ 1996: $86-91$ 
Li H, Jiao JJ (2003b) Tide-induced seawater-groundwater circulation in a multi-layered coastal leaky aquifer system. J Hydrol 274(1-4):211224. https://doi.org/10.1016/S002-1694(02)00413-4

Li G, Li H, Boufadel MC (2008) The enhancing effect of the elastic storage of the seabed aquitard on the tide-induced groundwater head fluctuation in confined submarine aquifer systems. J Hydrol 350(12):83-92. https://doi.org/10.1016/j.jhydrol.2007.11.037

Logan WS, Auge MP, Panarello HO (1999) Bicarbonate, sulfate, and chloride water in a shallow, clastic-dominated coastal flow system, Argentina. Groundwater 37(2)287-295

Mancino C, Vives L, Funes A, Zárate M, Martínez S (2013) Modelación del flujo subterráneo en la cuenca Matanza-Riachuelo, provincia de Buenos Aires: 1. geología y geometría del subsuelo [Modeling of the underground flow in the Matanza-Riachuelo basin, province of Buenos Aires: 1. geology and geometry of the subsoil]. Temas Actuales de La Hidrología Subterránea, Editorial de la Universidad Nacional de La Plata, La Plata, Argentina

Meinzer OE (1928) Compressibility and elasticity of artesian aquifers. Econ Geol 23(3):263-291. https://doi.org/10.2113/gsecongeo.23.3.263

Monachesi LB, Guarracino L (2011) Exact and approximate analytical solutions of groundwater response to tidal fluctuations in a theoretical inhomogeneous coastal confined aquifer. Hydrogeol J 19:14431449. https://doi.org/10.1007/s10040-011-0761-y

Narasimhan TN, Kanehiro BY, Witherspoon PA (1984) Interpretation of earth tide response of three deep, confined aquifers (USA). J Geophys Res 89(B3):1913-1924. https://doi.org/10.1029/ JB089iB03p01913

Park HY, Jang K, Ju JW, Yeo IW (2012) Hydrogeological characterization of seawater intrusion in tidally-forced coastal fractured bedrock aquifer. J Hydrol 446-447:77-89. https://doi.org/10.1016/j.jhydrol. 2012.04.033

Pugh DT (1987) Tides, surges and mean sea-level. Mar Petrol Geol 5(3). https://doi.org/10.1016/0264-8172(88)90013-x

Rasmussen TC, Crawford LA (1997) Identifying and removing barometric pressure effects in confined and unconfined aquifers. Ground Water 35(3):502-511. https://doi.org/10.1111/j.1745-6584.1997. tb00111.x

Renard P, Allard D (2013) Connectivity metrics for subsurface flow and transport. Adv Water Resour 51:168-196. https://doi.org/10.1016/j. advwatres.2011.12.001

Renau-Pruñonosa A, Morell I, Pulido-Velazquez D (2016) A methodology to analyse and assess pumping management strategies in coastal aquifers to avoid degradation due to seawater intrusion problems. Water Resour Manag 30(13):4823-4837. https://doi.org/10.1007/ s11269-016-1455-y

Rice JR, Cleary MP (1976) Some basic stress diffusion solutions for fluid-saturated elastic porous media with compressible constituents. Rev Geophys 14(2):227-241. https://doi.org/10.1029/ RG014i002p00227

Santoro P, Fernández M, Fossati M, Cazes G, Terra R, Piedra-Cueva I (2011) Pre-operational forecasting of sea level height for the Río de la Plata. Appl Math Modell 35(5):2462-2478. https://doi.org/10. 1016/j.apm.2010.11.065

Shirahata K, Yoshimoto S, Tsuchihara T, Ishida S (2018) Heterogeneous hydraulic properties of an insular aquifer clarified by a tidal response method with simple decomposition techniques. Geologia-Croatica, pp 83-90. https://doi.org/10.4154/gc.2018.06

Simionato CG, Vera CS, Siegismund F (2005) Surface wind variability on seasonal and interannual scales over Río de la Plata area. J Coastal Res 214:770-783. https://doi.org/10.2112/008-nis.1

Slooten LJ, Carrera J, Castro E, Fernandez-Garcia D (2010) A sensitivity analysis of tide-induced head fluctuations in coastal aquifers. J Hydrol 393(3-4):370-380. https://doi.org/10.1016/j.jhydrol.2010. 08.032
Song Z, Li L, Kong J, Zhang H (2007) A new analytical solution of tidal water table fluctuations in a coastal unconfined aquifer. J Hydrol 340(3-4):256-260. https://doi.org/10.1016/j.jhydrol.2007.04.015

Teloglou IS, Bansal RK (2012) Transient solution for stream-unconfined aquifer interaction due to time varying stream head and in the presence of leakage. J Hydrol 428-429:68-79. https://doi.org/10.1016/j. jhydrol.2012.01.024

Teo HT, Jeng DS, Seymour BR, Barry DA, Li L (2003) A new analytical solution for water table fluctuations in coastal aquifers with sloping beaches. Adv Water Resour 26(12):1239-1247. https://doi.org/10. 1016/j.advwatres.2003.08.004

Terzaghi K (1925) Principles of soil mechanics: a summary of experimental studies of clay and sand. McGraw-Hill, New York

Terzaghi K (1954) Theoretical soil mechanics. Wiley, Chichester, UK

Tófalo OR, Etchichury MC, Fresina M (2005) Características texturales y petrofacies de depósitos neógenos, Bancalari, provincia de Buenos Aires. Rev Asoc Geol Argent 60(2):316-326

Trefry MG, Bekele E (2004) Structural characterization of an island aquifer via tidal methods. Water Resour Res 40(1):1-21. https://doi.org/ 10.1029/2003WR002003

Trinchero P, Sánchez-Vila X, Fernàndez-Garcia D (2008) Point-to-point connectivity, an abstract concept or a key issue for risk assessment studies? Adv Water Resour 31(12):1742-1753. https://doi.org/10. 1016/j.advwatres.2008.09.001

Tyukhova AR, Willmann M (2016) Connectivity metrics based on the path of smallest resistance. Adv Water Resour 88:14-20. https://doi. org/10.1016/j.advwatres.2015.11.014

Vallejos A, Sola F, Pulido-Bosch A (2014) Processes influencing groundwater level and the freshwater-saltwater interface in a coastal aquifer. Water Resour Manag 29(3):679-697. https://doi.org/10.1007/ s11269-014-0621-3

van der Kamp G (1972). Tidal fluctuations in a confined aquifer extending under the sea. Proc. 24th Int. Geol. Congr., Montreal, 1972, pp 101-106

Van Der Kamp G, Gale JE (1983) Theory of earth tide and barometric effects in porous formations with compressible grains. Water Resour Res 19(2):538-544. https://doi.org/10.1029/WR019i002p00538

Vives L, Scioli C, Mancino C, Martínez S (2013) Modelación del flujo subterráneo e n la cuenca Matanza - Riachuelo, Provincia de Buenos Aires. 3. Modelo numérico de flujo. In: González N, Kruse EE, TrovattoMM, Laurencena P (eds) Temas actuales de la hidrología subterránea. pp 101-108. http://sedici.unlp.edu.ar/handle/10915/ 30338. Accessed March 2021

Wang X, Li H, Wan L, Liu F, Jiang X (2012) Loading effect of water table variation and density effect on tidal head fluctuations in a coastal aquifer system. Water Resour Res 48(9):1-15 https://doi. org/10.1029/2011WR011600

Wang C, Li H, Wan L, Wang X, Jiang X (2014) Closed-form analytical solutions incorporating pumping and tidal effects in various coastal aquifer systems. Adv Water Resour 69:1-12. https://doi.org/10. 1016/j.advwatres.2014.03.003

Willmann M, Carrera J, Sánchez-Vila X (2008) Transport upscaling in heterogeneous aquifers: what physical parameters control memory functions? Water Resour Res 44(12). https://doi.org/10.1029/ 2007WR006531

Zabala ME, Martínez S, Manzano M, Vives L (2016) Groundwater chemical baseline values to assess the Recovery Plan in the Matanza-Riachuelo River basin, Argentina. Sci Total Environ 541: 1516-1530. https://doi.org/10.1016/j.scitotenv.2015.10.006

Publisher's note Springer Nature remains neutral with regard to jurisdictional claims in published maps and institutional affiliations. 